\title{
22
}

\section{Palaeoecology as a means of auditing wetland condition}

\section{Peter Gell}

Centre for Environmental Management, University of Ballarat, Ballarat, Victoria

p.gell@ballarat.edu.au

\author{
The line it is drawn, the curse it is cast \\ The slow one now, will later be fast \\ As the present now, will later be past \\ The order is rapidly fadin' \\ And the first one now will later be last \\ For the times they are a changin'
}

Bob Dylan

\section{Introduction}

One could line up a suite of palaeoecological research papers published about Australian sites and, while they would not extend from Lake Wangoom to Lynch's Crater, they would fill much of the pollen microscope laboratory at Monash University. In one way, that, in fact, would be the best place to start to assemble the bibliography, as many of the papers have emanated from Peter Kershaw and the long list of honours and postgraduate students he has supervised, his post-doctoral fellows and the palaeoecological diaspora that is the legacy of this legend from Littleborough. Of course, all of these students would suggest it be assembled elsewhere, as they know too well that it would take many years to find all of the papers in Peter's office.

If this list was separated into those with a long-term focus and those with a direct management focus, there would be a clear bias to the former. While Peter's supervisor patiently examined detailed records of change in fine temporal (and spatial) resolution (Walker et al. 2000), and first coined the term 'fine-resolution pollen analysis', his student's focus was clearly on the ecological response of vegetation communities to Milankovich-scale climatic fluctuations. The pollen record from Lynch's Crater is progressively developed in an ever increasing number of publications (Kershaw 1978, 1986, 1993; Turney et al. 2006; Kershaw et 
al. 2007) and this is complemented by long offshore records (Harle 1997; Moss and Kershaw 2007) and those from the western plains (Kershaw et al. 1991; Kershaw, 1998; Harle et al. 2004), and uplands (McKenzie and Kershaw 1997; Kershaw et al. 2007) of Victoria. While Peter Kershaw's website observes that his research focus is on "Environmental Change ... as a basis for understanding present landscapes and contributing to their future management", Peter has only occasionally ventured into the dark side of environmental management. Perhaps he shied away after the Queensland Forestry Commission used his Lynch's Crater pollen diagram in a brochure justifying rainforest logging (Figure 1) and, in doing so, changed the chronology from thousands to millions of years, reversed the time frame and postulated that humans (Homo erectus!) arrived in Australia at 1.5 million years ago (Kershaw and Gell 1990). Despite this, Peter rightly holds a firm view that these long-term records are relevant to management, but his passion for the large, deep-in-time changes kept him largely temporally isolated from those doing the managing. The charge of examining more recent time frames, in fine detail, was left to his students (Gell et al. 1993), and his students' students (Bickford et al. 2008), and these have, more or less, helped or hindered managers, depending on your point of view.

a.

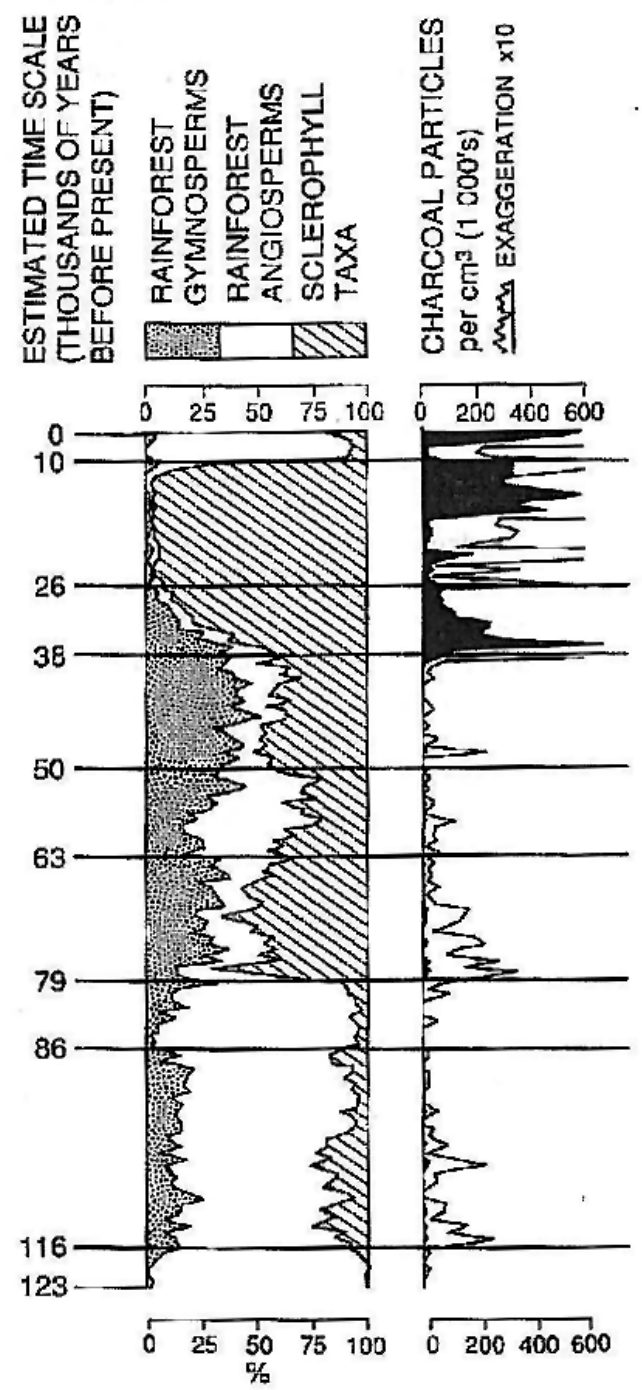

b.

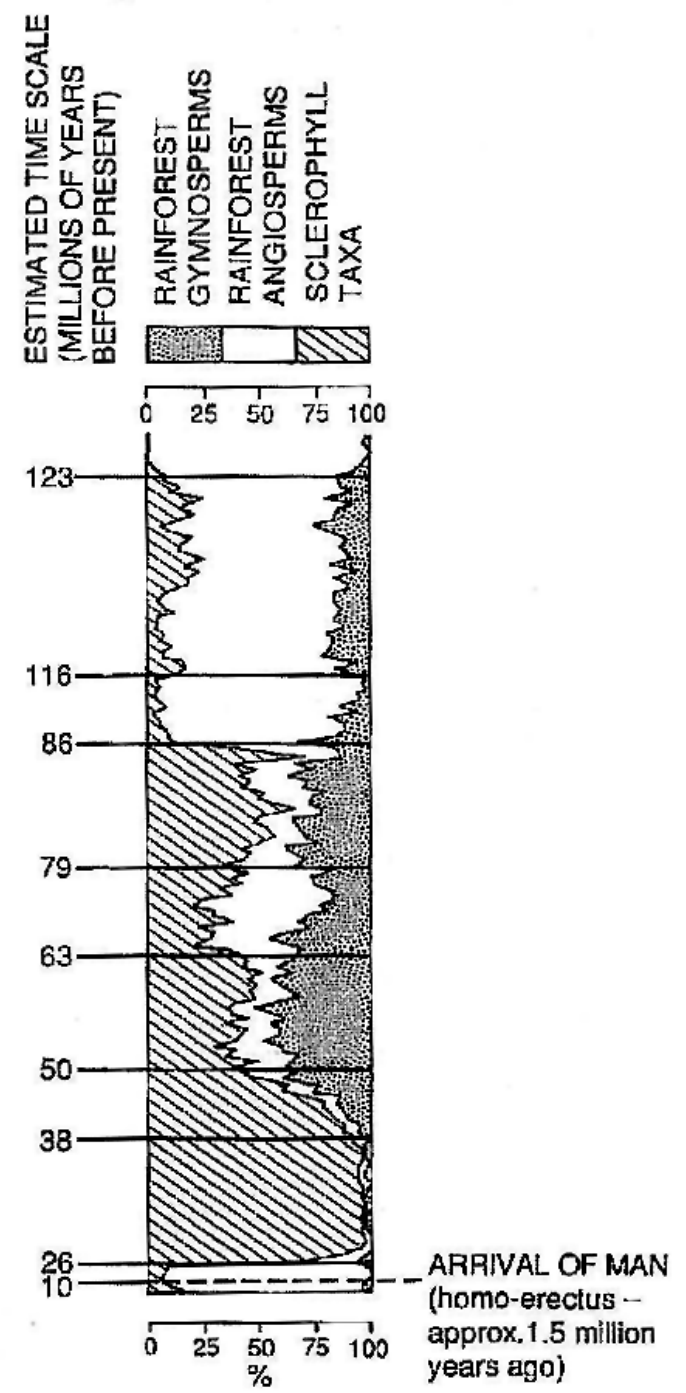

Figure 1. The pollen record from Lynch's Crater as (re)interpreted by the Queensland Forestry Commission (from Kershaw and Gell 1990). 


\section{Management questions}

Particularly over the past decade, there has been an explosion of research directed towards applied ecology, undertaken with a view to generating evidence to assist environmental managers make effective decisions. Increasingly, these have been fully replicated research designs dedicated to establishing sufficient power of analysis to demonstrate both significance and repeatability. Also, they have been analysed or modelled using increasingly sophisticated statistical techniques that reveal, at least to the statistician, what the data is showing in terms of identifiable changes or causal relations. However, these are contemporary studies, and so, by their very nature, do not address the forces that lead to the management issues at hand. As Weatherhead (1986) observed, managers tend to use the right techniques to address the wrong questions. In Australia, the evidence of very early, post-European settlement landscape destabilisation (Gale and Haworth 2002), salinisation (Gell et al. 2005a), eutrophication (Gell and Little 2006) and sediment flux (Reid et al. 2002, 2007) is testament to the fact that contemporary ecologists are researching already disturbed, and sometimes degraded, ecosystems.

There are several management questions that require a historical, and palaeoecological, approach. For wetland managers, palaeolimnological approaches can provide critical evidence relating to:

- The heritage status of a wetland by assessing its present condition against its long-term range of variability.

- The sensitivity or resilience of a wetland by retrospectively assessing its ecological response to past perturbations.

- The prognosis of a wetland by identifying its trajectory of change or infilling.

- The drivers of wetland change by associating past ecological shifts with documented shifts in climate or management regime.

- The health of the wetland by identifying the degree to which it has departed from its historical range of variability (Bennion and Battarbee 2007).

In all cases, in Australia, where the shift in ecological condition predated the 1970s, these questions cannot be answered by contemporary ecological research.

For wetlands and their managers, the magnitude of the recent 'Big Dry'very much sharpened, perhaps for the first time, their focus on the history of drought and the trajectories of wetland condition subjected to reduced effective rainfall within substantially disturbed catchments. The types of questions asked included:

- What are the effects of clearfell harvesting on aquatic systems?

- What is the natural ecological character of this wetland (e.g. for reviews of status under the Ramsar protocol)?

- What are the main drivers of river and wetland change and what should be the management target for our wetland?

- Is this drought unusual and if so what is the cyclicity of events of this magnitude?

\section{Impact of clearfell harvesting}

The lag in vegetation, and so pollen, response to catchment changes often means that palynological evidence is not a decisive measure of the impact of direct human impacts, such as clearfell harvesting. The more responsive nature of the aquatic biota, however, has proved to be incisive, as demonstrated in the case of Tea Tree Swamp on the Delegate River (Gell and 
Stuart 1989). The Delegate River drains the northern slopes of the Errinundra Plateau, East Gippsland, which is a large area of Victoria's forest estate that was subject to considerable environmental debate in the 1980s (Mercer 1995). Short, fine-resolution pollen and charcoal records were generated with a view to assessing the changes to the catchment through the European period, in association with an ethnohistoric study of catchment settlement and use. While some forest understorey taxa (e.g. Tasmannia) were shown to be sensitive to the postsettlement fire regimes, the most dramatic changes in the pollen flora were identified to be in the uppermost sediments. In three different cores, taxa with reproductive life histories sensitive to swamp drying (Sphagnum and Myriophyllum pedunculatum) increased in representation by orders of magnitude in the upper sediments deposited after 1970 AD (Gell et al. 1993). The timing of this change coincided with the commencement of forest harvesting in the catchment. By the time of the study, almost half the forest had been clearfelled. While the 12,000-year record of Ladd (1979) was of coarser resolution, this very recent change was unprecedented, and attested to the significance of the hydrological impact of ash forest regeneration on this scale (Figure 2). This phenomenon was documented in the classic Correnderrk catchment study using space-for-time substitution (Kuczera 1985), and the combination of this modelling approach and the palaeoecological record (Wilby and Gell 1994) was able to document conclusively the opportunity cost in terms of water yield of intensively harvesting tall, ash forests. The outcome also identified clearfell harvesting as the driver of change that led a state-listed wetland outside its range of historic variability.

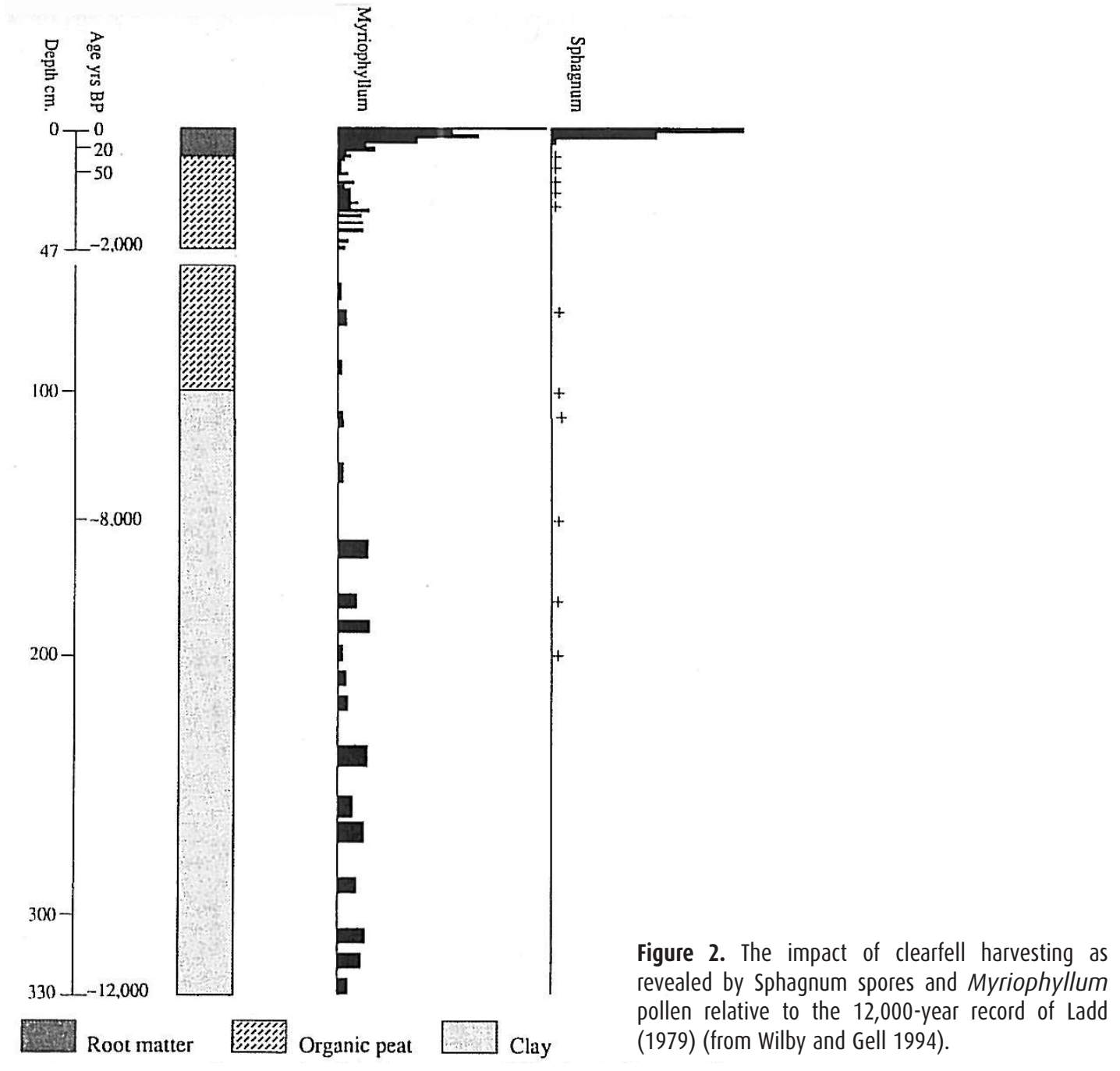




\section{Assessment of natural ecological character}

The International Treaty on Wetlands of International Significance was signed in Ramsar, Iran, in 1971. Australia, as a signatory, listed many wetlands in the early years. As part of this process, nominations were required to state the natural ecological character of the wetland, as well as the attributes for which it qualified under a range of criteria. One such wetland was the Coorong, a $110 \mathrm{~km}$ long back-dune lagoon adjacent to the mouth of the River Murray. It was listed in 1985 and its ecological character was described as (DEH 2000):

The Coorong, Lake Alexandrina \& Lake Albert. 01/11/85; South Australia; 140,500 ha; 3556’S 139¹8'E. National Park, Game Reserves. Shorebird Network Site. A saline to hypersaline lagoon separated from the ocean by a dune peninsula and connected to two lakes forming a wetland system at the river's mouth. The lakes contain fresh to brackish water. The site is of international importance for migratory waterbirds, providing habitat for more than $30 \%$ of the waders summering in Australia. The site includes important nesting colonies of waterbirds. The globally endangered Orangebellied Parrot over-winters on the reserve. The area is noted for its extensive aboriginal, historic and geological sites.

To preserve this saline to hypersaline state, an embargo was placed on releases of freshwater from the upper southeast of South Australia, via Salt Creek. Effectively, no more than $45 \mathrm{ML}$ was to be released lest the condition of the lagoon become too fresh. As the rate of water abstraction across the Murray-Darling Basin increased, and the regional climate shifted from a flood to a drought-dominated regime, the mouth of the Murray River closed and the salinity of the Coorong rapidly increased to as much as $220 \mathrm{~g} / \mathrm{L}$ in its southern waters. As the salinity increased, the populations of fish and waterbirds, which underpinned the initial nomination, declined. This lead to calls for the dedication of $700 \mathrm{GL}$ of river water into the system to save the Coorong and adjacent lakes (Gell 2010). Palaeolimnological evidence from cores taken the length of the Coorong revealed it to have a subsaline history with little direct contribution from the river (Fluin et al.2007), as revealed by very low levels of the river plankter Aulacoseira granulata (Figure 3). In fact, it was highly reliant on freshwater contributions from Salt Creek. The embargo on these, based on the misidentification of its natural ecological character during its Ramsar listing, as well as the commissioning of weirs to limit the tidal prism into the lakes, was a driver of its hypersalinity. This lead to a depletion in its decomposer flora, which drove a net accumulation of carbon (McKirdy et al. 2010). The elevated carbon oxygen demand led to sediment anoxia which extinguished much of its invertebrate biota and its functional Ruppia autotroph community (Krull et al. 2009; Dick et al. In press). Clearly, the lack of historical context was fatal to the state of this internationally significant wetland and brings into question the merits of the expenditure of several million dollars of research on the contemporary ecology of this degraded system.

\section{Managing floodplain wetlands}

The records of wetland change along the floodplain of the River Murray and its tributaries provide evidence for management to understand the drivers of ecological change and the natural ecological condition of wetlands, which may form 'aspirational' targets of restoration efforts. While they clearly contradict the views of the irrigation lobby that the case for degradation has been exaggerated (Benson et al. 2003), they also provide clear warnings for managers that the mere provision of environmental flows is not sufficient to alleviate the problems associated with 


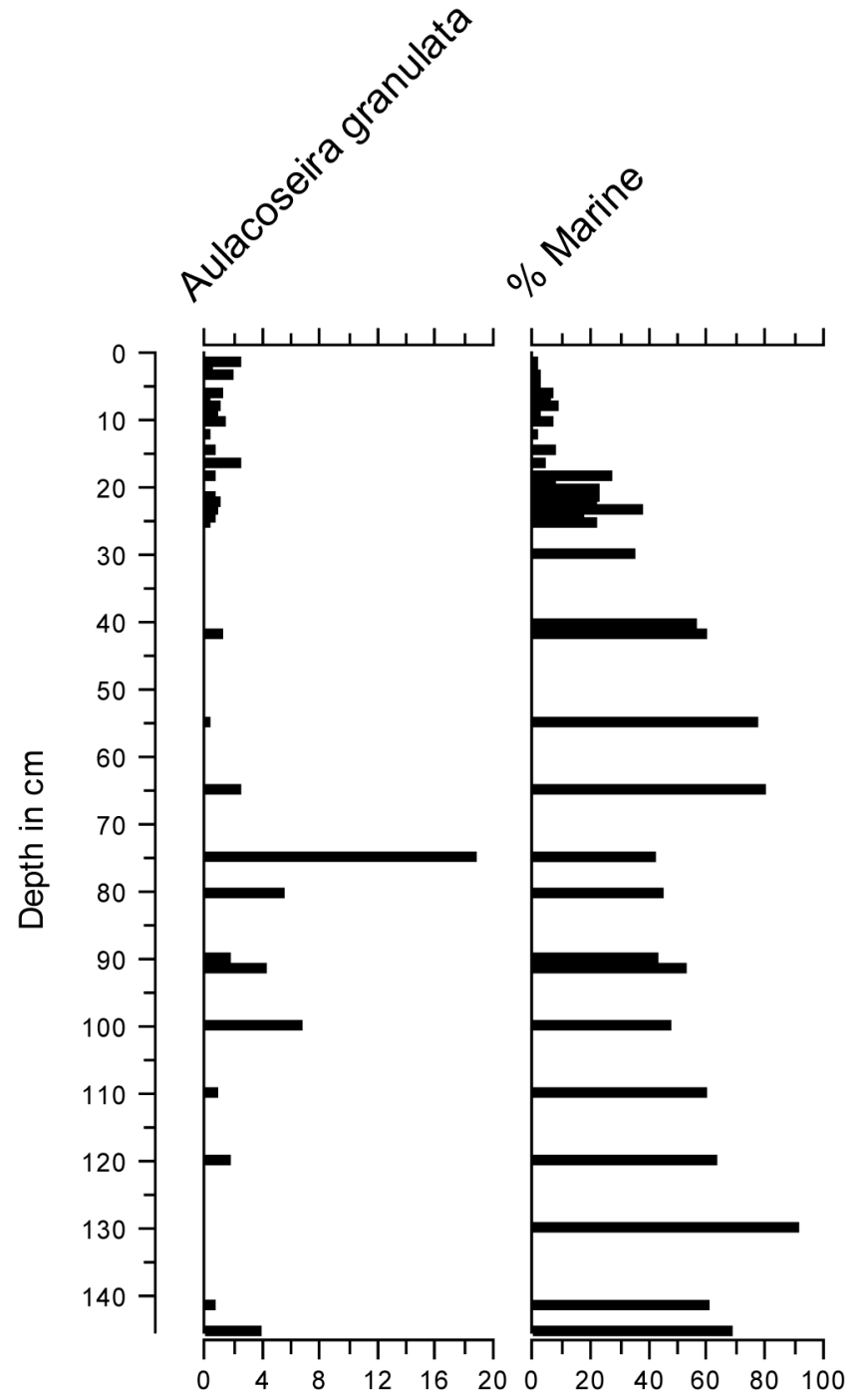

Figure 3. The record of Aulacoseiro granulato from the north lagoon of the Coorong, revealing the lack of direct influence of the River Murray. The proportion of marine taxa reveals the influence of the tidal prism on the ecological character of the lagoon. Data from Fluin et al. 2007.

excessive sedimentation, salinisation and eutrophication.

Several of the Monash diaspora have undertaken research on the limnology (Gell et al.2002; Tibby et al.2003; Tibby 2004; Tibby and Reid 2004; Philibert et al.2006) and palaeolimnology of floodplain wetlands from the upper (Reid et al. 2002; Tibby et al. 2003) to the lowermost reaches above the terminal lakes (Gell et al. 2005a, b, 2007a; Gell and Little 2006; Fluin et al. 2010; Gell 2010). The palaeodiatom records were assembled in a larger database as part of the Environmental Futures Network working group OZPACS (Figure 4), which endeavoured to provide temporal context to the management of Australian ecosystems (Fitzsimmons et al. 2007). A metadata analysis of the Murray Darling Basin sites reveals that considerable change has taken place, and that the diatom assemblages of all MDB sites differ markedly from their 'natural' historical range of variability. At a superficial level, this contradicts the claims of Benson et al. (2003), and suggests that the degraded state of the wetlands of the MDB has been underestimated.

Ogden and Reid (Thoms et al. 1999; Ogden 2000; Reid et al. 2002) were the first to demonstrate the demise of the basin's productive wetlands by illustrating the shift in diatom and cladoceran assemblages from predominantly epiphytic forms to communities dominated by plankton. This shift is a consequence of a change in the light regime, itself impacted by the increased flux in fine sediments, leading to turbid waters. This effect has similarly been revealed in wetlands down-catchment, mainly revealed through the widespread colonisation of sites by 


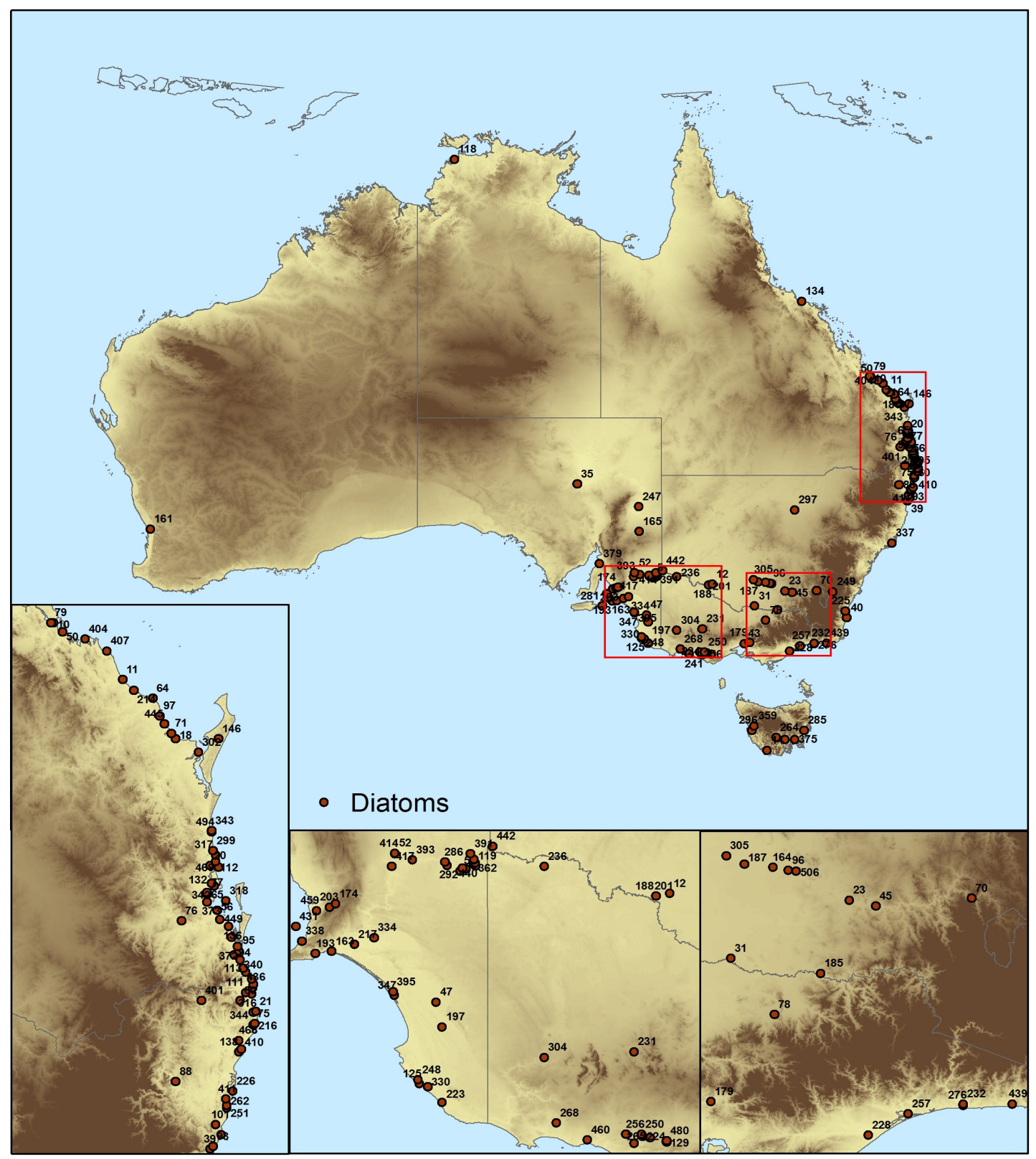

Figure 4. The metadatabase of diatom records across eastern Australia from the 0ZPACS website.

low-light-tolerant, tychoplanktonic diatoms within the Fragilariaceae (Gell et al. 2009a). This has been supported by consistent evidence for increased sediment accumulation rates. These have increased five to 80 fold, attaining up to $40 \mathrm{~mm} /$ year, raising the prospect that these shallow wetlands are at risk of complete infilling. This process is further accelerated through sediment accretion by aquatic plants that have increased their abundance since regulation (Figure 5) and as wetlands infill (Gell et al. 2006). Additionally, there is evidence for early salinisation (Gell et al. 2005b) and eutrophication (Gell and Little 2006), and, more recently, acidification (Gell 2010). Several of these stressors appear to have commenced concurrently, prompting Gell et al. (2007b) to suggest co-variation between drivers of change and stressors on condition. In effect, however, calls for water allocations to reverse the degradation of the wetlands of the Murray Darling Basin are somewhat facile when faced with the body of evidence now assembled more fully revealing their plight. 


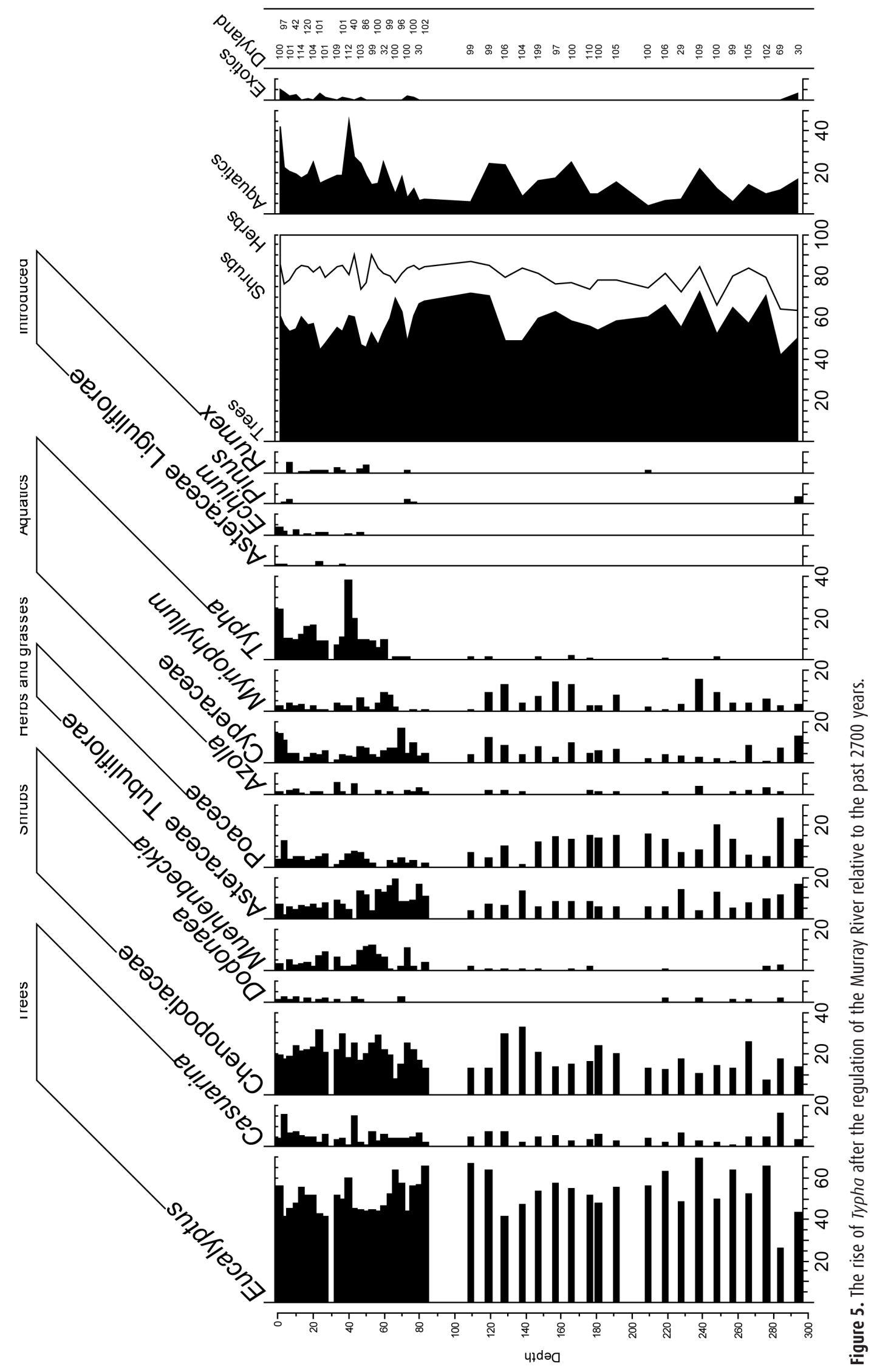




\section{Drought}

It is pleasing to muse that the goals of those who drove the wealth of long-term, palaeoclimate research in Australia tended to shy from the environmental debate, and that now, past climates are central to the greatest environmental challenge of our time. It is amusing also to recognise that this has drawn the focus to examining the past 2000 years in detail to provide context, in the manner of the 'Hockey Stick' of Mann et al. (1998), to the present climatic circumstances. The assemblage of the record of data of Australia's climate over this time frame is being advanced by several means, including through the IGBP PAGES-supported AUS2k workshop (Gergis and Turney 2010) and the Palaeoclimates relevant to NRM in the MDB workshop and report (Gell et al. 2009b). While the goal of deriving climate metrics from sediment records remains a challenge, it is clear from the emerging records that droughts of considerable duration have occurred in the recent past (Barr 2010), that wetlands have changed significantly in the absence of industrialised people across this time frame (Mills et al. 2010), and that the recent 'big dry' is unusual at the millennial timescale.

\section{Conclusion}

While not necessarily the primary goal of Peter Kershaw, a clear legacy of his contribution to palaeoecological science is the production of a diverse array of research, undertaken in fine resolution, that has been directed at addressing recent environmental change with the deliberate and direct intention of informing natural resource management. From this research, we understand that most of our aquatic ecosystems are degraded and are under considerable ongoing stress through increasing fluxes of salts, nutrients and sediments under hydrological dry conditions wrought by a drought of unusual duration and depth. We can say with confidence that many wetlands are now in unprecedented condition and that the demands of managers have never been so acute.

Some of the lessons for managers include the reality that some resource-extraction activities have a clear opportunity cost in terms of water yield. In the context of the recent drought, it is even clearer now that catchment activities should be focussed firstly on prioritising water yield over other consumptive activities. There is a lesson from the Coorong that, where goals for restoration or rehabilitation are to be set, the identification of those goals should include a palaeoecologically derived understanding of the natural condition and audit of the present status before management measures are implemented. A further and perhaps final lesson is that palaeoecology can provide the only means of understanding the drivers of wetland change as contemporary ecological approaches can only experiment on derived systems. The evidence from the MDB wetlands reveals that these sites changed very early after settlement, have been stressed by multiple drivers of change and are unlikely to be remediated in a sustainable way by the mere provision of river water. In this instance, we can advocate that the allocation of scarce water resources should be limited to those sites that have already implemented measures to control the influx of salts, nutrients and sediments.

As a postscript, it can be noted that much of this research emerged in the 20th century but has rarely been incorporated into restoration plans or management measures. It remains true that 'Despite the obvious importance of the historical approach, there is a reluctance on the part of planners and managers to take full account of its implications' (Kershaw and Gell 1990:19). It is clear, therefore, that there remains considerable scope for an improved program of the extension of this knowledge to the broader natural resource management community. As with all science, there is both a reluctance to, and considerable incentives not to, engage with research users through the production of outputs and presentation at fora that do not provide 
good return to the academic's institution. While the national research priorities continue to draw research into applied priorities, and 'Water - a critical resource' is a clear, relevant example, there remains an obligation for outputs to be palatable for end users so that the management measures implemented are targeted, timely and effective.

\section{References}

Barr, C. 2010. Droughts and Flooding Rains: A fine-resolution reconstruction of climatic variability in southeastern Australia over the last 1500 years. Unpublished $\mathrm{PhD}$ thesis, The University of Adelaide.

Bennion, H. and Battarbee, R.W. 2007. The European Union Water Framework Directive: opportunities for paleolimnology. Journal of Paleolimnology 38:285-295.

Benson, L., Markham, A. and Smith, R. 2003. The Science Behind the Living Murray Initiative. Deniliquin: Murray Irrigation Limited.

Bickford, S., Gell, P. and Hancock, G.J. 2008. Wetland and terrestrial vegetation change since European settlement on the Fleurieu Peninsula, South Australia. The Holocene 18:425-436.

Department of Environment and Heritage 2000. Coorong, and Lakes Alexandrina and Albert Ramsar Management Plan. Adelaide: Government of South Australia.

Dick, J., Haynes, D., Tibby, J., Garcia, A. and Gell, P. 2011. A history of aquatic plants in the Ramsar-listed Coorong wetland, South Australia. Journal of Paleolimnology. Doi: 10.1007/ s10933-011-9510-4.

Fitzsimmons, K.E., Gell, P.A., Bickford, S., Barrows, T.T., Mooney, S.D. and Denham, T.P. 2007. The OZPACS database: A resource for understanding recent impacts on Australian ecosystems. Quaternary Australasia 24:2-6.

Fluin,J., Gell, P., Haynes, D. and Tibby,J.2007. Paleolimnological evidence for the independent evolution of neighbouring terminallakes, the Murray Darling Basin, Australia.Hydrobiologia 591:117-134.

Fluin, J., Tibby, J. and Gell, P. 2010. Testing the efficacy of electrical conductivity (EC) reconstructions from the lower Murray River (SE Australia): a comparison between measured and inferred EC. Journal of Paleolimnology 43:309-322.

Gale, S.J. and Haworth, R.J. 2002. Beyond the limits of location: human environmental disturbance prior to official European contact in early colonial Australia. Archaeology in Oceania 37:123-136.

Gell, P. 2010. With the benefit of hindsight: The utility of palaeoecology in wetland condition assessment and identification of restoration targets. In: Batty, L. and Hallberg, K. (eds), Ecology of Industrial Pollution, pp. 162-188. Cambridge: CUP and the British Ecological Society.

Gell, P.A. and Stuart, I.-M. 1989. Human settlement history and environmental impact: the Delegate River catchment, East Gippsland. Monash Publications in Geography no. 36.

Gell, P.A., Stuart, I.-M. and Smith, J.D. 1993. The response of vegetation to changing fire regimes and human activity in the Delegate River catchment, East Gippsland, Victoria. The Holocene 3(2):150-160.

Gell, P.A., Sluiter, I.R. and Fluin, J. 2002. Seasonal and inter-annual variations in diatom assemblages in Murray River-connected wetlands in northwest Victoria, Australia. Marine and Freshwater Research 53:981-992.

Gell, P., Bulpin, S., Wallbrink, P., Bickford, S. and Hancock, G. 2005a. Tareena Billabong A palaeolimnological history of an everchanging wetland, Chowilla Floodplain, lower Murray-Darling Basin. Marine and Freshwater Research 56:441-456. 
Gell, P., Tibby, J., Fluin, J., Leahy, P., Reid, M., Adamson, K., Bulpin, S., MacGregor, A., Wallbrink, P., Hancock, G. and Walsh, B. 2005b. Accessing limnological change and variability using fossil diatom assemblages, south-east Australia. River Research and Applications 21:257-269.

Gell, P., Fluin, J., Tibby, J., Haynes, D., Khanum, S., Walsh, B., Hancock, G., Harrison, J., Zawadzki, A. and Little, F. 2006. Changing Fluxes of Sediments and Salts as Recorded in lower River Murray wetlands, Australia. International Association of Hydrological Sciences 306:416-424.

Gell,P. and Little, F.2006. Water Quality History of Murrumbidgee River Floodplain Wetlands. Wagga Wagga: Murrumbidgee Catchment Management Authority.

Gell, P., Baldwin, D., Little, F., Tibby, J. and Hancock, G. 2007a. The impact of regulation and salinisation on floodplain lakes: the lower River Murray, Australia. Hydrobiologia 591:135-146.

Gell, P., Jones, R. and MacGregor, A. 2007b. The sensitivity of wetlands and water resources to climate and catchment change, south-eastern Australia. PAGES Nerws 15 (1):13-15.

Gell, P., Fluin, J., Tibby, J., Hancock, G., Harrison, J., Zawadzki, A., Haynes, D., Khanum, S., Little, F. and Walsh, B. 2009a. Anthropogenic Acceleration of Sediment Accretion in Lowland Floodplain Wetlands, Murray-Darling Basin, Australia. Geomorphology 108:122-126.

Gell, P., Gergis, J., Mills, K., Baker, P., De Deckker, P., Finlayson, M., Hesse, P., Jones, R., Kershaw, P., Pearson, S., Treble, P., Barr, C., Brookhouse, M., Drysdale, R., Haberle, S., Karoly, D., McDonald, J., Thoms, M. and Tibby, J. 2009b. Palaeoclimates relevant to NRM in the MDB. Canberra: Murray-Darling Basin Authority.

Gergis, J. and Turney, C. (eds) 2010. The First Australian 2k (AUS2K) PAGES Regional Workshop: Towards Data Synthesis. Unpublished workshop programme and abstract booklet.

Harle, K. 1997. Late Quaternary vegetation and climate change in southeastern Australia: palynological evidence from marine core E55-6. Palaeogeography, Palaeoclimatology, Palaeoecology 161:465-483.

Harle, K.J., Kershaw, A.P. and Clayton, E. 2004. Patterns of vegetation change in southwest Victoria (Australia) over the last two glacial/interglacial cycles. Proceedings, Royal Society of Victoria 116:107-139.

Kershaw, A.P. 1978. Record of last interglacial-glacial cycle from north-eastern Queensland. Nature 272:159-161.

Kershaw, A.P. 1986. Climatic change and Aboriginal burning in north-east Australia during the last two glacial/interglacial cycles. Nature 322:47-49.

Kershaw, A.P., D'Costa, D.M., McEwan-Mason,J.R.C. and Wagstaff, B.E. 1991.Palynological evidence for Quaternary vegetation and environments of mainland southeastern Australia. Quaternary Science Revierws 10:391-404.

Kershaw, A.P., McKenzie, G.M., Porch, N., Roberts, R.G., Brown, J., Heijnis, H., Orr, L.M., Jacobsen, G. and Newall, P.R. 2007. A high resolution record of vegetation and climate through the last glacial cycle from Caledonia Fen, south-eastern highlands of Australia. Journal of Quaternary Science 22:481-500.

Kershaw, A.P. 1993. Palynology, biostratigraphy and human impact. The Artefact 16:12-18.

Kershaw, A.P. 1998. Estimates of regional climatic variation within south-eastern mainland Australia since the Last Glacial Maximum from pollen data. Paleoclimates: Data and Modelling 3:107-134.

Kershaw, A.P. and Gell, P.A. 1990. Quaternary vegetation and the future of the forests. In: Bishop, P. (ed), Lessons for human survival: nature's record from the Quaternary. Geological Society 
of Australia Symposium Proceedings 1:11-20.

Krull, E., Haynes, D., Lamontagne, S., Gell, P., McKirdy, D., Hancock, G., McGowan, J. and Smernik, R. 2009. Changes in the chemistry of sedimentary organic matter within the Coorong over space and time. Biogeochemistry 92:9-25.

Kuczera, G. 1985. Predictions of water yield reductions following bushfire in ash-mixed species eucalypt forest. Melbourne: Melbourne and Metropolitan Board of Works report No. MMBW-W-0014.

Ladd, P.G. 1979. Past and present vegetation on the Delegate River in the highlands of eastern Victoria, II. Vegetation and climate history from $12000 \mathrm{BP}$ to present. Australian Journal of Botany 27:185-202.

Mann, M.E., Bradley, R.S. and Hughes, M.K. 1998. Global-scale temperature patterns and climate forcing over the past six centuries. Nature 392:779-787.

McKenzie, G.M. and Kershaw, A.P. 1997. A vegetation history and quantitative estimate of Holocene climate from Chapple Vale, in the Otway Region of Victoria, Australia. Australian Journal of Botany 45:565-581.

McKirdy, D.M., Thorpe, C.S., Haynes, D.E., Grice, K., Krull, E.S., Halverson, G.P., Webster, L.J. 2010. The biogeochemical evolution of the Coorong during the mid- to late Holocene: An elemental, isotopic and biomarker perspective. Organic Geochemistry 41:96-110.

Mercer, D. 1995. A Question of Balance. Sydney: Federation Press.

Mills, K., Gell, P., Kershaw, A.P., MacKenzie, M. and Lewis, T. 2010. Evidence for a preEuropean drought in the western Victorian lakes: a historical context for the recent Victorian drought? In: Gergis, J. and Turney, C. (eds), The First Australian 2k (AUS2K) PAGES Regional Workshop: Towards Data Synthesis. 27: Melbourne University: Unpublished workshop programme and abstract booklet.

Moss, P.T. and Kershaw, A.P. 2007. A late Quaternary marine palynological record (oxygen isotope stages 1 to 7 ) for the humid tropics of northeastern Australia based on ODP site 820'. Palaeogeography, Palaeoclimatology, Palaeoecology 251:4-22.

Ogden, R.W.2000. Modern and historical variation in aquatic macrophyte cover of billabongs associated with catchment development. Regulated Rivers: Research and Management 16: 487-512.

Philibert, A., Gell, P., Newall, P., Chessman, B. and Bate, N. 2006. Development of diatombased tools for assessing stream water quality in south eastern Australia: Assessment of environmental transfer functions. Hydrobiologia 572:103-114.

Reid,M., Fluin, J., Ogden, R.,Tibby,J. and Kershaw, P.2002. Long-term perspectives on human impacts on floodplain-river ecosystems, Murray-Darling Basin, Australia. Verhandlungen der Internationalen Vereinigung für Theoretische und Angewandte Limnologie 28(2):710-716.

Reid, M.A. and Ogden, R.W. 2009. Factors affecting diatom distribution in floodplain lakes of the southeast Murray Basin, Australia and implications for palaeolimnological studies. Journal of Paleolimnology 41(3):453-470.

Reid, M.A., Sayer, C.D., Kershaw, A.P. and Heijnis, H. 2007. Palaeolimnological evidence for submerged plant loss in a floodplain lake associated with accelerated catchment erosion (Murray River, Australia). Journal of Paleolimnology 38:191-208.

Thoms, M.C., Ogden, R.W. and Reid, M.A. 1999. Establishing the condition of lowland floodplain rivers: a palaeo-ecological approach. Freshwater Biology 41:407-423.

Tibby, J. and Reid, M. 2004. A model for inferring past conductivity in low salinity waters derived from Murray River (Australia) diatom plankton. Marine and Freshwater Research 55:597-607.

Tibby, J., Reid, M.A., Fluin, J., Hart, B.T. and Kershaw, A.P. 2003. Assessing long-term pH change in an Australian river catchment using monitoring and palaeolimnological data. 
Environmental Science and Technology 37(15):3250-3255.

Tibby, J. 2004. Development of a diatom-based model for inferring total phosphorus in southeastern Australian water storages. Journal of Paleolimnology 31:23-36.

Turney, C.S.M., Kershaw, A.P., Lowe, J.J., van der Kaars, S., Johnston, R., Rule, S., Moss, P., Radke, L., Tibby, J., McGlone, M.S., Wilmshurst, J.M., Vandergoes, M.J., Fitzsimons, S.J., Bryant, C., James, S., Branch, N.P., Cowley, J., Kalin, R.M., Ogle, N., Jacobsen, G. and Fifield, L.K. 2006. Climatic variability in the southwest Pacific during the Last Termination (20-10 kyr BP). Quaternary Science Reviews 25:886-903.

Walker, D., Head, M.J., Hancock, G.J. and Murray, A.S. 2000. Establishing a chronology for the last 1000 years of laminated mud accumulation at Lake Barrine, a tropical upland maar lake, northeastern Australia. The Holocene 10:415-427.

Weatherhead, P.J. 1986. How unusual are unusual events? American Naturalist 128:150-154.

Wilby, R.L. and Gell, P.A. 1994. The impact of forest harvesting on water yield: modelling hydrological changes detected by pollen analysis. Journal of Hydrological Sciences 39 (5):471486. 